\title{
A Community-Engaged Faculty Typology: A Self-Referent Approach to Understanding Faculty Perspectives
}

\author{
Emily Morrison and Wendy Wagner \\ The George Washington University
}

\begin{abstract}
While there are various theories about faculty involvement in community-engaged scholarship (CES), there is little understanding of how faculty approach and make meaning of CES for themselves (Morrison $\&$ Wagner, 2016). The purpose of this study was (a) to determine if a typology can represent the variety of ways in which faculty approach and make meaning of CES, and if so, then (b) to provide a rich description of the perspective of each "type." Data analysis using Q Methodology and focus groups of faculty who self-identified as being engaged in the community revealed a Community-Engaged Faculty Typology, with five distinct types. Each type is described in detail, followed by a discussion of the emergent typology, its limitations, and its implications for research, theory, and practice. Specifically, the findings from this study suggest that all five approaches to CES should be considered when training, developing programs, supporting, and reviewing the contributions of community-engaged faculty.
\end{abstract}

To thrive in the 21st century, higher education must adopt new approaches in order to move engagement from the margin to the mainstream of its research, teaching, and service. To become fully embedded into the central core of the institution, engagement must be scholarly; cut across the missions of teaching, research, and service; be reciprocal and mutually beneficial; and embrace the process and values of civil democracy (Bringle \& Hatcher, 2011) . . . Faculty involvement and support are essential for furthering the institutionalization of engagement. (Fitzgerald, Bruns, Sonka, Furco, \& Swanson, 2016, pp. 239-240)

Over the past 25 years, a new form of scholarship - the "scholarship of engagement" (SOE) - has emerged that broadens and deepens the connection between academic scholarship and the public (Barker, 2004). Boyer (1990, 1996) introduced SOE as a new direction for the civic renewal of higher education in the United States, asserting that being a scholar goes beyond conducting original research and "means stepping back from one's investigation, looking for connections, building bridges between theory and practice, and communicating one's knowledge effectively to students" (1990, p. 16). The SOE addressed the growing concern that the work of the academy was becoming increasingly distanced from the public good (Delve, Mintz, \& Stewart, 1990; Ehrlich, 2000; Kezar, Chambers, \& Burkhardt, 2005; Newman, 1985; Saltmarsh, 2011a; Zlotkowski, 2011). The SOE required a new epistemology (Fear \& Sandmann, 2016; Saltmarsh, 2011b; Schon, 1995) and offered a strong theoretical foundation from which to reconnect colleges and universities with their original civic aims and reexamine faculty roles, the latter being the focus of this study (Ehrlich, 2000; Fear \& Sandmann; Fitzgerald et al.; Lynton, 1994, 1995; Rice, 1996; Saltmarsh \& Hartley, 2016; Stanton, 2008; Ward, 2003; Zlotkowski, 2011).

Faculty play an essential role in bringing the SOE to life by partnering with communities and bridging academia with community-identified concerns (Fitzgerald et al., 2016) through communityengaged scholarship (CES) (Welch, 2016). While an institution's administrators provide important leadership to foster engagement, it is the faculty who take action with community partners and build the connections between scholarship and service (Ward, 2003). The scholarship on communityengaged faculty is growing quickly (Demb \& Wade, 2012; O'Meara, 2008; O'Meara, Sandmann, Saltmarsh, \& Giles, 2010; Pearl, 2015; Post, Ward, Longo, \& Saltmarsh, 2016; Rice, Sorcinelli, \& Austin, 2000; Townson, 2009; Wade \& Demb, 2009) and shows an increasing awareness of differences among faculty who practice CES in their approaches to, motivations for, and the language used to describe their work (Barker, 2004; Demb \& Wade, 2012; Glass, Doberneck, \& Schweitzer, 2011; O'Meara \& Niehaus, 2009; Pearl, 2015; 
Townson, 2009; Wade \& Demb, 2009). Synthesizing the literature on community-engaged faculty, Demb and Wade (2012) developed a comprehensive Faculty Engagement Model (FEM), which consists of personal, professional, institutional, and communal dimensions comprising 24 factors that interact and influence if and how a faculty member engages in scholarly community work, which illustrates the complexity involved in understanding CES among faculty.

Adding to the complexity, community-engaged faculty may find themselves marginalized in two different ways. First, community-engaged faculty may encounter questions about the legitimacy of their work when contrasted with traditional scholarship (O'Meara, 2016) in institutional cultures that are "not hospitable to emerging forms of scholarship" (Saltmarsh \& Hartley, 2016, p. 25). Institutional policies and practices, particularly those related to promotion and reward structures, often fail to value or recognize CES, resulting in an inability to fully enact their missions (Furco, 2010). These institutions also fail to attract and retain community-engaged faculty - especially next generation scholars who seek academic work with the public now rather than once tenure has been earned (Post et al., 2016; Welch, 2016) - to fill positions left by a substantial wave of retirements (Fitzgerald et al., 2016). Second, marginalization may occur within the community of engaged faculty themselves. In both the literature and in practice, community-engaged faculty are often treated as a relatively homogenous group (Buzinski et al., 2013; Pearl, 2015), which minimizes, if not ignores, the ways in which faculty differ in their approaches, priorities, needs, and motivations. For instance, in a particular institution's anthropology department, engaging students in direct, individual service experiences may be the norm. However, a faculty member in that department may engage her students in team-based capacity-building projects because of her particular course learning goals and personal priorities related to having a sustainable community impact. Both approaches to scholarly engagement are legitimate. However, this faculty member may find her work marginalized by her peers if they do not see her students' work as "real" community engagement.

Recognizing the role faculty play in CES and helping their institutions "retain social relevancy and public legitimacy" (Fitzgerald et al., 2016; Post et al., 2016, p. 1), additional research on community-engaged faculty is needed, timely, and relevant. Specifically, research is needed that explores the complexities surrounding faculty CES in a way that honors faculty perspectives that may have been previously marginalized. Approaching research in this way allows faculty to make meaning of CES for themselves and allows researchers a way to look for patterns in how faculty make meaning of CES. Thus, the purpose of this study is twofold: (a) to determine if a typology can represent the variety of ways in which faculty approach and make meaning of CES, and if so, then (b) to provide a rich description of the perspective of each type.

\section{Theoretical Framework}

To explore and classify community-engaged faculty members' perspectives on CES, communityengaged faculty must have an opportunity to share their perspective without being constrained by operationalized variables defined by researchers (Morrison \& Wagner, 2016). Thus, to provide a wide range of perspectives on scholarship and community engagement, we chose Boyer's (1990, 1996) four forms of scholarship and Morton's (1995) three paradigms of service to structure our theoretical framework given their predominance in the field. By offering broader perspectives on both scholarship and service rather than using narrower conceptualizations of CES operationalized by researchers, study participants are able to indicate what is most salient to them regarding the intersection of scholarship and service with fewer predetermined constraints.

\section{Conceptualizations of Scholarship}

Boyer's (1990, 1996) reconceptualization of scholarship expands the definition of scholarship to include not only discovery, but also integration with other disciplines, application of knowledge to relevant issues in the community, and teaching in ways that extends and transforms knowledge. These four elements of scholarship inform and are informed by one another. Specifically, the scholarship of discovery involves pursuing knowledge through scholarly investigation. Discovery is at the heart of the academy and is what most people think of as "research." Research is essential, but insufficient (1996). Knowledge - and discovery in particular - needs to be contextualized and understood from multiple perspectives. The scholarship of integration involves synthesizing knowledge, making connections across disciplines, and reexamining findings to identify new meanings that may lead to more comprehensive understanding (1990). To remain relevant, knowledge needs to be useful. The scholarship of application involves moving back and forth between theory, practice, and research (1996), as well as addressing "consequential prob- 
lems" (1990, p. 21). In fact, Boyer went as far as asking, "can social problems themselves define an agenda for scholarly investigation" (1990, p. 21)? As important as it is to discover, integrate, and apply knowledge, it is also essential to teach. The scholarship of teaching, or what Boyer also refers to as the "scholarship of sharing knowledge" (1996, p. 17), emphasizes that teaching is a dynamic endeavor where knowledge is "not only transmit[ed] . . , but transform[ed] and extend[ed]" (1990, p. 24). Thus, knowledge only becomes consequential when others understand it.

\section{Conceptualizations of Service}

At the same time notions of scholarship were evolving (Boyer, 1990, 1996; Lynton, 1994; Rice, 1996; Saltmarsh, 2011b; Schön, 1983, 1987, 1995), the service movement was refining the various manifestations of community engagement (e.g., volunteerism, service-learning, community-based research, advocacy, outreach, etc.) (Eyler \& Giles, 1999; Fear \& Sandmann, 1995; Kendall, 1990; Kretzmann \& McKnight, 1993; Morton, 1995; Sandmann, 2008; Stanton, Giles, \& Cruz, 1999). Specific attention was focused on intentionally bridging community service with learning (Furco, 1996; Porter-Honnet \& Poulsen, 1990; Sigmon, 1994) as a way to deepen student learning (Astin \& Sax, 1998; Astin, Sax, \& Avalos, 1999; Astin, Vogelgesang, Ikeda, \& Yee, 2000; Eyler, Giles, \& Braxton, 1997) and fulfill higher education's civic responsibility (Ehrlich, 2000; Saltmarsh, 2011a; Welch, 2016). (For a concise overview of the history, see Jacoby, 2015).

As the service-learning movement emerged, scholars critically reflected on and debated the purposes of engaging students in the community. Kendall (1990) posited that service-learning should move students from a mindset of charity toward a mindset of social justice to better address the root causes of systemic social inequalities (see also Eyler \& Giles, 1999). Rather than a continuum from charity to social justice, Morton (1995) proposed three distinct paradigms of service: charity, project development, and social change. These paradigms help explain individuals' motivations for service, as well as their relative impacts on a community.

Each paradigm in Morton's model has its own worldview and "ways of identifying and addressing problems, and long-term visions of individual and community transformation" (1995, p. 21). Charity generally involves direct service, has a shorter time commitment, and thus a limited impact on those being served. Projects "focus on defining problems and their solutions and implementing well- conceived plans for achieving those solutions" ( $\mathrm{p}$. $21)$ thereby requiring greater effort and long-term planning. Social change is a more transformative model of service, focused on an examination of the social systems and structures that need to change in order to eliminate the inequities that result in the need for charity or project approaches. Morton described each of these paradigms as having a "thin" or "thick" approach, with greater thickness representing increased attention to building relationships in the community and deeper understanding of the root causes of the problems being addressed. Morton's theory does not privilege one paradigm of service over another; instead, he championed serving from any of these paradigms with greater integrity and authenticity.

\section{Community-Engaged Scholarship Classifications}

The SOE and service movements continue to evolve simultaneously and when woven together, inform the dynamic and emerging field of CES. Scholars have begun to try to make sense of this complexity by creating different classifications of community-engaged faculty (Barker, 2004; Buzinski et al., 2013; O'Meara, 2008; Pearl, 2015; Townson, 2009).

O'Meara (2008) identified a typology of seven faculty motivations for community engagement that cut across several themes in the literature on motivation, including one extrinsic motivation (e.g., institutional supports and rewards), three individual motivations (e.g., student learning, scholarly pursuits, or impact on a social issue or in a community), and three intrinsic motivations (e.g., personal identity, professional identity, and a desire for collaboration). Barker (2004) identified a taxonomy of emerging engaged practices including public scholarship, participatory research, community partnership, public information networks, and civic literacy scholarship. Pearl (2015) created a typology of community-engaged faculty based on the practices faculty engage in, resulting in five distinct groups (community-engaged scholars, aspirational engagers, passive engagers, traditional scholars, and generational engagers). Both Townson (2009) and Buzinski et al. (2013) examined the influence of academic discipline on faculty engagement in the community by classifying faculty into disciplinary categories either by type (pure/hard; pure/soft; applied/hard; applied/soft) or field (i.e., humanities, STEM, applied professions, and social sciences), respectively.

With the exception of O'Meara's typology of community-engaged faculty motivations, the exist- 
ing faculty classifications (Barker, 2004; Buzinski et al., 2013; Pearl, 2015; Townson, 2009) are based on externally observed variables like discipline and engaged practices rather than on how the faculty themselves make sense of their CES work. As such, these classifications may be more reflective of the researchers' ways of making meaning of CES than that of the faculty themselves (Morrison \& Wagner, 2016).

\section{Method}

Q Methodology is a research philosophy and approach that studies people's overall subjective points of view on a construct, identifying patterns within and across the responses. Q Method (or Q Technique), the procedure used to achieve that goal, sorts study participants (e.g., community-engaged faculty) into groups based on a shared overall perspective on the study topic (Brown, 1980; McKeown \& Thomas, 1988; Stephenson, 1953). If distinct groups emerge, then a typology is created. Thus, Q Methodology enables faculty in this study to express their own way of conceptualizing CES rather than responding to our operationalized definition as the researchers, and offers us a way to determine if a typology of engaged community-faculty exists. This approach is a unique intersection of qualitative and quantitative methods that may not be familiar to all; therefore, the data collection and analysis processes are described in depth.

\section{Participants (Person Set)}

In terms of generalizable findings, Q Method is more qualitative in nature and does not rely on large random samples or proportionate sampling strategies that quantitative methods would employ. Rather, researchers select a relatively small Person Set that is intentionally inclusive of the variety of perspectives they wish to explore. For this study, we collaborated with various departments and centers at a comprehensive private not-for-profit university, classified as an "R1: Doctoral University: highest research activity" (The Carnegie Classification of Institutions of Higher Education, n.d.) to recruit self-identified community-engaged faculty to participate in the study. We directly e-mailed 522 faculty about participation in the study, with the goal of creating a Person Set that included a variety of engaged scholarship practices, faculty contract types (e.g., tenure, contract, adjunct, etc.), disciplines, and colleges. In addition to the targeted invitation, research study information and invitations were sent out via departmental listservs. Reminder and follow-up emails were issued on an iterative basis to maximize the diverse representation of the Person Set.

To explore participants' self-referent perspectives on CES, any faculty member who selfidentified as "community-engaged" was allowed to participate in the study. We were careful not to predefine the meaning of CES (e.g., "What counts as community-engaged?" or "What counts as scholarship?") when selecting and inviting participants; instead, we left these open to interpretation. In total, the Person Set included 61 participants who completed the Q Sort and background form. The Person Set included a wide-range of disciplines, position types (e.g., tenured, contract/term, adjunct), age, ethnicity, and gender (see Table 1).

\section{Instrument (Q Set)}

In Q Method, the instrument is called the Q Set, which is a set of printed index cards with one statement per card that participants in the $\mathrm{P}$ (Person) Set sort in a way that reflects their own

Table 1

Demographic Characteristics of the Participants

\begin{tabular}{lr}
\hline Number of Participants & 61 \\
Contract Type & \\
Tenured & $33 \%$ \\
Tenure Track & $13 \%$ \\
Term Contract & $28 \%$ \\
Adjunct & $11 \%$ \\
Part-time & $7 \%$ \\
Other/Not Reported & $8 \%$ \\
Discipline & \\
Health & $21 \%$ \\
Humanities & $20 \%$ \\
Social Science & $18 \%$ \\
Public Policy/Law & $11 \%$ \\
Physical/Natural Sciences & $10 \%$ \\
Business & $8 \%$ \\
Technology/Engineering/Math & $7 \%$ \\
Education/Counseling & $5 \%$ \\
Gender & \\
Female & $69 \%$ \\
Male & $28 \%$ \\
Not Reported & $3 \%$ \\
Race/Ethnicity & \\
White/Caucasian & \\
Black/African-American & $72 \%$ \\
Hispanic/Chicano & $11 \%$ \\
Asian-American & $8 \%$ \\
Not Reported & $3 \%$ \\
Age & $5 \%$ \\
$70-79$ & \\
$60-69$ & $3 \%$ \\
50-59 & $25 \%$ \\
40-49 & $25 \%$ \\
$30-39$ & $23 \%$ \\
Not Reported & $16 \%$ \\
\hline & \\
& \\
&
\end{tabular}


Figure 1

Sample Q Sort Layout and Scoring

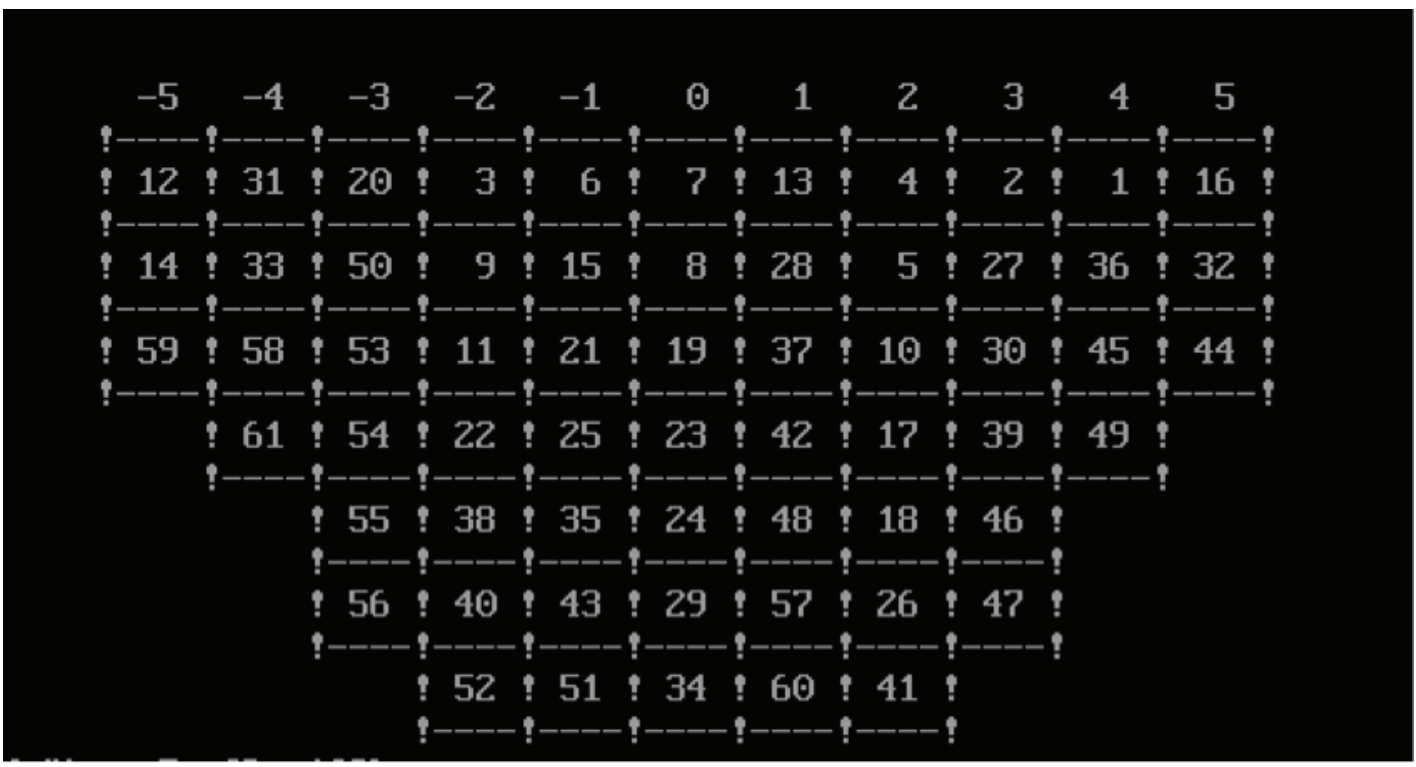

Note. Figure 1 illustrates how a participant sorted the Q Set and the researchers recorded the data for analysis.

meaning making. To create the Q Set, we generated as many statements expressing the relevant ideas and opinions on the topic of CES as possible by deconstructing the various meanings of "scholarship," "service," and their intersections. To ensure the Q Set items included a breadth of possible perspectives, the items were structured using Boyer's (1990, 1996) and Morton's (1995) respective theoretical frameworks to create statements that articulated the potential viewpoints on the nature of scholarly work and service represented in those frameworks. To provide a sufficient range of perspectives in the Q Set, while at the same time keeping the study's focus tightly set on faculty's internal frame of reference regarding aspects of scholarship and service, we added a few statements drawn from the literature. The additional items addressed issues related to identity ties to discipline, appreciation of opportunities for collaboration (O'Meara, 2008), personal commitment to specific people or community organizations (Bringle, Hatcher \& McIntosh, 2006; O'Meara, 2008), and beliefs about the role of scholarship in public discourse (Burawoy, 2005). Complementing the items drawn from the literature, an invited group of community-engaged faculty participated in an item generation focus group where they discussed various dimensions of engagement, offering nuance and "common language" to the ideas represented. From this large set of statements, we selected 61 items for the final Q Set (examples included in the findings section), which falls within the optimal Q Set guidelines of between 40-80 statements (Brown, 1980; Watts $\&$ Stenner, 2005). Each of the statements was assigned a random number to facilitate data analysis. The fact that there were the same number of items in the Q Set as participants in the P Set was purely coincidental.

\section{Procedure (Q Sort)}

After reviewing the purposes of the study and establishing informed consent, we gave the participants the Q Set. Following procedures outlined by Brown (1980) and McKeown and Thomas (1988), participants reviewed all of the statements and were instructed to divide the cards into three piles according to their level of agreement with each statement: agree, disagree, and neutral (i.e., unsure, do not know, or simply do not care about the statement). From there, participants further separated the cards along an established continuum with 11 columns ranging from least to most agreement. Each column was allowed a certain number of cards (see Figure 1). To begin this next step of subdivision, participants started with their "agree pile," selecting the three statements they felt most strongly about. Then, from the remaining cards, they selected four additional statements with which they felt most strongly about and so forth, moving through the neutral and disagree piles in turn, until all of the cards were sorted into the respective 
degrees of agreement columns. We continually emphasized to participants that the continuum had no fixed point in which "agree with" items became "disagree with" items. Rather, placement of all items was considered to be in relation to the other items. On average, participants completed the cardsort process in approximately 30 minutes.

Participant Q Sorts were recorded on a score sheet that collected each Q Set statement number in columns representing the stack it appeared in. Specifically, each of the 11 columns were labeled -5 (least) to +5 (most) agreement (see Figure 1) to facilitate data analysis. Participants then completed a brief background form that gathered information regarding their discipline, contract type, and experience with a variety of forms of community engagement, such as community-based research and service-learning, along with demographic information. The background form was intentionally completed after the Q Sort to minimize any stereotyperelevant effects (Armenta, 2010; Shih, Ambady, Richeson, Fujita, \& Gray, 2002; Steele \& Aronson, 1995).

Following initial analysis and interpretation of the Q Sort results, we invited all of the participants to attend one of three 90-minute focus groups to member check and further clarify the perspectives represented by each resulting factor. Eighteen participants, who represented all five resulting factors, participated in the focus groups.

\section{Data Analysis}

The results of the $61 \mathrm{Q}$ Sorts were analyzed using PQMethod, a Q Method software package. Through Principal Components Analysis, the Q Sorts of each study participant were used to find groups, or factors, of participants with similar views. We considered several factor structures (from three to eight factors) in order to find the best representation of the data. A participant only loaded onto a factor if the factor explained more than half of the common variance of the Q Sorts and was significant at $p<.05$ (Schmolck, 2002). We used the PQMethod software to flag the Q Sorts that were "pure" representations of a certain factor (i.e., Q Sorts that only loaded onto one particular factor). A few participants did not load onto any factor. Their Q Sorts represented perspectives that are either partially represented by more than one factor (i.e., their Q Sorts do not load onto a sole factor) or have more idiosyncratic perspectives that are not represented by the factors that emerged here. For a factor to be considered reliable, at least five participants should load onto it (Brown, 1980). After examining the data, we chose a five-factor structure, with each factor having between 5 and 13 participants loading onto it, meeting - if not exceeding - the standard for Q Method.

We then used PQMethod to create a factor-array for each of the five factors. A factor-array is best described as a composite Q Sort of the participants that loaded highly and unambiguously onto that factor. Factor weights were used to account for some participants loading more strongly onto the factor than others. The qualitative/quantitative nature of Q Methodology (Brown, 1980; Watts \& Stenner, 2005) and the overall point of view reflected by the Q Sort results in more nuanced classification than a typical quantitative study would produce. Although purely quantitative methods of classification result in types that are mutually exclusive and exhaustive, Q makes no claim to accomplish exhaustive or distinct categories but instead uses classification as a way to understand participant perspectives more deeply (Stephenson, 1953). For example, some participants might be moderately associated with two or three groups (Morf, Miller \& Syrotuik, 1976). However, it is important to reiterate that only pure representations of each factor were used to create the composite Q Sort for that factor.

We also used PQMethod to identify distinguishing statements, which were items from the Q Set that participants in each factor sorted in significantly different ways than participants in other factors, as well as consensus statements, which were Q Set items that were sorted similarly by participants in all of the factors. We used this data to interpret and describe the unique perspectives represented by the participants in each factor and further refined the interpretations emerging from the memberchecking focus groups.

Finally, we interpreted each factor, working one factor at a time. We started by analyzing the relative rankings of all 61 items in the aggregate Q Sort for the factor, noting items with which participants most strongly agreed or disagreed (i.e., the statements sorted at the extreme ends of the continuum) as well as considered the items sorted nearer to the center. We also compared the rankings of statements across factors, revealing key distinctions among them. This process added clarity to the perspectives of faculty in that factor and resulted in an initial description of each factor type. We presented these descriptions to participants during the three aforementioned focus groups, which ranged from five to eight participants per group. Insights from the focus groups about the perspectives of each faculty type were incorporated into the final factor descriptions presented here. In addition, we reviewed the information collected from participant background forms to see if any patterns emerged in relation to 
demographics, discipline, or contract type within or across the factors. We found that some factors were more heavily represented by faculty with tenure or by faculty from certain disciplines. These trends are reported with the intent of creating a fuller picture of the factors that emerged in this study. However, it is important to note that these trends do not indicate a statistically significant (i.e., generalizable) correlation between these demographics and type.

\section{Findings: Interpretation of the Factors}

Prior to exploring the findings, three important notes to consider. First, the order in which the factors are presented does not represent a hierarchy, imply a ranking, or suggest a particular proportion of each faculty type appearing in the general population. The results of a Q Methodology study indicate that the point of view of each factor exists. Any generalizations to the larger population that go beyond the existence of that distinct point of view on CES among engaged faculty are inappropriate. Second, all of the findings are from communityengaged scholars. Third, we have labeled each of the resulting factors with an heuristic intended to offer parameters of understanding about each factor's distinct perspective, invite deeper consideration, and facilitate discussion while recognizing the limitations of language.

\section{Factor Descriptions}

To begin, we offer a brief, overview table of the five faculty types as an initial framework from which to explore the findings. The factors are described in turn, each with a selection of Q Set statements and comparative rankings from the composite Q Sorts. It is important to note that the selected statements presented for each factor are statements that illustrate how each factor is distinct from the others. While the numbers offer an initial starting place for analysis, it is how all of the statements are ranked in comparison to each other that makes the presented statements meaningful. A detailed summary table is provided at the conclusion of the factor descriptions.

\section{Educators Advancing their Field (EAF)}

Faculty loading onto this factor strongly identify with being scholars. They value their connection to the academy, which they see as playing a positive role in society as a source of new knowledge and insights, as well as developing educated citizens. Faculty in this type value all four forms of Boyer's broadened notion of scholarship and see each form as mutually reinforcing. For example, their research informs and is informed by integration, application, and teaching. Their teaching is enhanced by opportunities for students to apply knowledge through experiential learning. In fact, some do not conceptualize their teaching role as limited to the classroom; for them, that role also includes mentoring and supervising field experiences.

These faculty are more likely to be navigating a traditional academic career path as they are able. While being able to make a positive difference in the community makes their work more meaningful, they see themselves as scholars first and foremost. In fact, when defining the "community they serve," many identified their professional community (e.g., "K12 teachers," "management", or "clinical psychologists") as well as their colleagues and students in their department and university. While their scholarly work may not actually occur in or have immediate benefits for the community beyond the academy, the purpose of their work is ultimately to benefit communities broadly speaking by equipping others to take action and educating students who will become practitioners in their field. A wide range of disciplines were represented in this group: social and natural sciences, humanities, business, and math. By far the largest portion were tenure-track or tenured faculty, although other contract types were represented. See Table 3 for select examples from the composite Q Sort for EAF faculty.

Table 2

Brief Overview of the Five Factors

\begin{tabular}{|c|c|c|c|c|c|}
\hline Factor Acronym & EAF & CAK & $\mathrm{RCC}$ & TACV & $\mathrm{CA}$ \\
\hline Heuristic & $\begin{array}{l}\text { Educators } \\
\text { Advancing their } \\
\text { Field }\end{array}$ & $\begin{array}{l}\text { Collaborators } \\
\text { Applying Knowl- } \\
\text { edge }\end{array}$ & $\begin{array}{l}\text { Researchers } \\
\text { in Community } \\
\text { Contexts }\end{array}$ & $\begin{array}{l}\text { Teachers Advanc- } \\
\text { ing Civic Values }\end{array}$ & $\begin{array}{l}\text { Community } \\
\text { Advocates }\end{array}$ \\
\hline $\begin{array}{l}\text { Primary } \\
\text { Motive for CES }\end{array}$ & $\begin{array}{l}\text { Generate disci- } \\
\text { plinary knowl- } \\
\text { edge }\end{array}$ & $\begin{array}{l}\text { Integrate and } \\
\text { apply disciplinary } \\
\text { knowledge } \\
\text { through collabo- } \\
\text { ration }\end{array}$ & $\begin{array}{l}\text { Value and incor- } \\
\text { porate community } \\
\text { voice in scholar- } \\
\text { ship }\end{array}$ & $\begin{array}{l}\text { Teach for lifelong } \\
\text { engagement while } \\
\text { building commu- } \\
\text { nity capacity }\end{array}$ & $\begin{array}{l}\text { Bridge communi- } \\
\text { ty and academia }\end{array}$ \\
\hline
\end{tabular}


Table 3

Select Statements from the Composite Q Sort for Educators Advancing their Field (EAF)

\begin{tabular}{|c|c|c|c|c|c|}
\hline Q Set Statement & EAF & CAK & $\mathrm{RCC}$ & TACV & $\mathrm{CA}$ \\
\hline The role of higher education is the discovery of new knowledge. & +4 & 0 & -1 & -3 & 0 \\
\hline $\begin{array}{l}\text { The role of higher education is to reveal new insights by integrating } \\
\text { knowledge across disciplines. }\end{array}$ & +4 & -1 & 0 & -2 & 0 \\
\hline $\begin{array}{l}\text { The most meaningful way that I work to make a difference in the } \\
\text { world is by the contributions I make to my discipline/field. }\end{array}$ & +3 & +1 & -1 & -3 & -3 \\
\hline $\begin{array}{l}\text { I see myself as an engaged community member first, and a scholar } \\
\text { second. }\end{array}$ & -5 & +2 & -3 & +1 & +4 \\
\hline $\begin{array}{l}\text { Our students should learn to apply course concepts/skills in the profes- } \\
\text { sional contexts in which they will work one day. }\end{array}$ & +5 & +4 & -2 & +3 & 0 \\
\hline As a teacher, I like to use any form of problem-based learning. & +4 & +1 & -1 & +1 & -2 \\
\hline
\end{tabular}

Table 4

Select Statements from the Composite Q Sort for Collaborators Applying Knowledge (CAK)

\begin{tabular}{|c|c|c|c|c|c|}
\hline Q Set Statement & EAF & CAK & $\mathrm{RCC}$ & TACV & $\mathrm{CA}$ \\
\hline $\begin{array}{l}\text { Through my community engagement, I enjoy opportunities to work } \\
\text { collaboratively with others. }\end{array}$ & +1 & +5 & +2 & -2 & +2 \\
\hline $\begin{array}{l}\text { I am able to communicate to my students and others how my discipline } \\
\text { benefits the community. }\end{array}$ & +2 & +4 & +2 & 0 & 0 \\
\hline $\begin{array}{l}\text { Through my community engagement, I have unique opportunities to } \\
\text { learn how ideas from my field integrate with those from other fields. }\end{array}$ & -1 & +3 & 0 & -1 & -2 \\
\hline $\begin{array}{l}\text { Professional internships are a great way for our students to engage in } \\
\text { the community. }\end{array}$ & +2 & +3 & -2 & 0 & -1 \\
\hline $\begin{array}{l}\text { The reason to engage students in the community is to foster critical } \\
\text { reflection on social structures/inequities that relate to course content. }\end{array}$ & +1 & -3 & +3 & +2 & +3 \\
\hline
\end{tabular}

Table 5

Select Statements from the Composite Q Sort for Researchers in Community Contexts (RCC)

\begin{tabular}{|c|c|c|c|c|c|}
\hline Q Set Statement & EAF & CAK & RCC & TACV & $\mathrm{CA}$ \\
\hline $\begin{array}{l}\text { Being a researcher/scholar who meaningfully engages in the community } \\
\text { is an important part of my identity. }\end{array}$ & -1 & +3 & +5 & +2 & -2 \\
\hline $\begin{array}{l}\text { My research is more current and relevant because of my engagement in } \\
\text { the community. }\end{array}$ & +1 & -1 & +5 & 0 & -4 \\
\hline It is important to be as aware of a community's assets as its needs. & +2 & +2 & +4 & -1 & +3 \\
\hline $\begin{array}{l}\text { Involvement in the community has influenced the direction of my } \\
\text { research/scholarship. }\end{array}$ & 0 & -2 & +3 & -1 & -1 \\
\hline
\end{tabular}

\section{Collaborators Applying Knowledge (CAK)}

Faculty loading onto this factor prefer to engage in community-based work that utilizes their disciplinary expertise and addresses immediate community needs through direct service, typically in ongoing partnerships with specific community organizations. They feel it is important to communicate to students, colleagues, and the broader community the relevance of their discipline and how it can benefit the community. Unique to this type is the extent to which these faculty enjoy working collaboratively with other colleagues within and beyond their own discipline in an effort to integrate knowledge in ways that address the needs presented by the community. Through community engage- ment, they have opportunities to learn how ideas from their discipline integrate with those from other fields.

The faculty in this group engage their students in direct service in the community, believing that it is critical that students have opportunities to apply disciplinary knowledge and skills in "real world" contexts. Their appreciation for experiential learning places equal value on civic participation, such as service-learning, and professional development, such as internships. This type is least focused on advocating for social or systemic change, preferring opportunities for direct service. The goal of such experiences is on building bridges between theory and practice by working through real situations to meet immediate needs. This factor had 
the greatest representation of STEM disciplines, although other disciplines were represented as well. The position types were a mix of tenure and term contract positions. See Table 4 for select examples from the composite Q Sort for CAK faculty.

\section{Researchers in Community Contexts (RCC)}

Participants who loaded onto this factor identify primarily as researchers, whose inquiries take place in and with specific communities. They are committed to making a positive difference in the community, and being able to do so through their research imbues their work with meaning and purpose. The communities with whom they work tend to be connected to their personal experiences and/ or background (e.g., their race, gender, or other aspects of identity). Their teaching role is also important to them, but research is primary. Both their research and teaching is aimed at social change, focusing on the root causes of social issues, within specific community contexts. They use their roles as engaged researchers and teachers, not only to raise public awareness about social issues in the community, but also to seek insight into how to address them by informing theory and practice.

This group of faculty expressed a markedly strong value for asset-based approaches to community engagement, emphasizing reciprocity in community-campus partnerships. As researchers, they value community members' experience and expertise and feel their research and teaching is more current and relevant given their engagement. Their research trajectory is informed by the community's voice. The participants in this group most often came from disciplines related to the public good, such as health, social sciences, and education. Most had positions that were tenure or tenuretrack. See Table 5 for select examples from the composite Q Sort for RCC faculty.

\section{Teachers Advancing Civic Values (TACV)}

Participants loading onto this factor identify primarily as teachers who engage students in the community to learn about issues related to civic engagement and social change in addition to expected course content. They believe that the best way for scholars to be involved in addressing the world's problems is through their role as teachers, challenging students to be critical thinkers, lifelong learners, and active citizens.

Depending on the course or the need expressed by the community, this faculty type may engage with students in direct service, project-based capacity-building, or advocacy work. Through facilitated reflection, these faculty prompt students to connect their service experiences (regardless of type) to the root causes of social issues and other social change concepts. They see themselves, their students, and their community partners as belonging to a larger human community. Their ideal partnership is for all parties involved - community members, students, and they themselves as faculty - to be considered both teachers and learners, with everyone involved gaining a better understanding of social issues and how to leverage social change. The disciplines represented in this factor were public policy/law, social sciences, and humanities. This factor had the greatest number of adjunct faculty; however, there was at least one participant from each of the position types included in the study. See Table 6 for select examples from the composite Q Sort for TACV faculty.

\section{Community Advocates (CA)}

While teaching is their primary form of scholarship, faculty who loaded onto the Community Advocates factor more strongly identify with the communities to which they belong than with their scholarly roles per se. They are community members first, which grounds and informs how and, for

Table 6

Select Statements from the Composite Q Sort for Teachers Advancing Civic Values (TACV)

\begin{tabular}{|c|c|c|c|c|c|}
\hline Q Set Statement & EAF & CAK & $\mathrm{RCC}$ & TACV & $\mathrm{CA}$ \\
\hline $\begin{array}{l}\text { Being a teacher who meaningfully engages students in the community is } \\
\text { an important part of my identity. }\end{array}$ & -1 & +1 & +4 & +5 & +1 \\
\hline $\begin{array}{l}\text { The best way for scholars to be involved in addressing today's social } \\
\text { problems is to teach students to be critical thinkers and lifelong learn- } \\
\text { ers with a sense of civic responsibility. }\end{array}$ & +5 & 0 & +2 & +5 & +4 \\
\hline $\begin{array}{l}\text { My teaching is more current and relevant because I am engaged in the } \\
\text { community. }\end{array}$ & +1 & +2 & +3 & +4 & +1 \\
\hline $\begin{array}{l}\text { Our students should work on projects that support organizations that } \\
\text { provide a community benefit. }\end{array}$ & 0 & 0 & -1 & +3 & +1 \\
\hline
\end{tabular}


some, even what and why they teach. This group of faculty is the most likely to define community as "us" rather than "them." Their desire to do engaged work is often influenced by aspects of their personal background or experience, including their social or cultural identities. This is the only faculty group to describe their engagement as an ongoing commitment to a specific group of people, community, or issue.

The faculty in this group believe the role of higher education is not just to understand the world, but also to improve it through addressing root causes of social issues and working for social change. Further, they believe the best way for scholars to be involved in addressing today's problems is by teaching students to be informed, engaged community members able to understand complex social issues and take action to influence change. Their work includes advocacy, raising awareness, and teaching students to be critical thinkers who understand issues from a systemic perspective. In this participant pool, Community Advocates were mainly in the health and humanities disciplines and largely in term contract positions. See Table 7 for select examples from the composite Q Sort for CA faculty.

\section{Summary of the Factors}

To illustrate the similarities and distinctions between the factors, Table 8 presents a summary of the five perspectives on CES that emerged through data analysis. This table is meant to serve as a tool that deepens understanding rather than be used as a reductive tool that oversimplifies the complexity within each perspective. Thus, it is important to remember that it is the unique combination of the different component perspectives that creates the factors.

\section{Discussion}

Building on the findings, this discussion features a deeper exploration of the CEF Typology revealed in this study with respect to community-engaged faculty's orientations to scholarship, orientations to service, intersections of scholarship and service, and identity and contributions. With this foundation, attention then turns to address the limitations and implications of this work.

\section{Orientations to Scholarship}

Faculty in each factor recognized the value of and need for all four forms of scholarship (Boyer, 1990) to varying degrees. Participants acknowledged that one form of scholarship often influenced the other forms of scholarship, if not intersecting in important ways. That being said, each factor had a primary orientation toward or preference for a particular form of scholarship. In other words, each factor had a central approach or place within the interconnected fabric of engagement that they preferred to work. Grounded in this central form of scholarship, engaged faculty found meaning and knowledge that served as a foundation from which to expand to less central forms of scholarship. For instance, RCC faculty use their research expertise to offer communities research findings that can be used to inform decisions and actions. With knowledge gleaned from this process, RCC faculty revise their teaching so that students are better prepared for evidence-based practice. In contrast, TACV faculty are primarily focused on teaching, seeing service-learning as an innovative pedagogy that fosters civic and course learning outcomes that may lead to integrating theories from other fields. EAF faculty are unique in that they emphasize the intersection between all four forms of scholarship. They do not prefer one form of scholarship over another; rather, they draw upon a particular form depending on the context.

Among the four types of scholarship, Boyer's discovery elicited the strongest reaction among focus group participants. They did not identify with traditional conceptualizations of "pure" research (i.e., controlled experimental designs driven by

Table 7

Select Statements from the Composite Q Sort for Community Advocates (CA)

\begin{tabular}{lccccc}
\hline \multicolumn{1}{c}{ Q Set Statement } & EAF & CAK & RCC & TACV & CA \\
\hline $\begin{array}{l}\text { My community engagement is generally focused on my ongoing com- } \\
\text { mitment to a specific group of people, community, or social issue. }\end{array}$ & -4 & 0 & +2 & 0 & $\mathbf{+ 5}$ \\
$\begin{array}{l}\text { I tend to build on-going relationships with the community members with } \\
\text { whom I work. }\end{array}$ & -2 & +2 & +1 & -3 & $\mathbf{+ 4}$ \\
$\begin{array}{l}\text { I see myself as an engaged community member first, and a scholar } \\
\quad \text { second. }\end{array}$ & -5 & +2 & -3 & +1 & $\mathbf{+ 4}$ \\
$\begin{array}{l}\text { I prefer to work with community members or organizations who are } \\
\text { advocating for social change. }\end{array}$ & -2 & -5 & +2 & +1 & $\mathbf{+ 3}$ \\
\hline
\end{tabular}


Table 8

Summary of the Factor Descriptions

\begin{tabular}{|c|c|c|c|c|c|}
\hline Acronym & EAF & CAK & $\mathrm{RCC}$ & TACV & $\mathrm{CA}$ \\
\hline Heuristic & $\begin{array}{l}\text { Educators } \\
\text { Advancing their } \\
\text { Field }\end{array}$ & $\begin{array}{l}\text { Collaborators } \\
\text { Applying Knowl- } \\
\text { edge }\end{array}$ & $\begin{array}{l}\text { Researchers } \\
\text { in Community } \\
\text { Contexts }\end{array}$ & $\begin{array}{l}\text { Teachers Advanc- } \\
\text { ing Civic Values }\end{array}$ & $\begin{array}{l}\text { Community } \\
\text { Advocates }\end{array}$ \\
\hline $\begin{array}{l}\text { Primary perspec- } \\
\text { tive on CES }\end{array}$ & $\begin{array}{l}\text { An integration of } \\
\text { the scholarship of } \\
\text { discovery, teach- } \\
\text { ing, integration, } \\
\text { and application in } \\
\text { order to gener- } \\
\text { ate disciplinary } \\
\text { knowledge }\end{array}$ & $\begin{array}{l}\text { Integrate and } \\
\text { apply disciplinary } \\
\text { expertise, often } \\
\text { in collaboration } \\
\text { with other faculty } \\
\text { and students, to } \\
\text { address immedi- } \\
\text { ate community } \\
\text { needs }\end{array}$ & $\begin{array}{l}\text { Research, } \\
\text { grounded in } \\
\text { relevant com- } \\
\text { munity contexts, } \\
\text { both to support } \\
\text { communities and } \\
\text { to capture and } \\
\text { share community } \\
\text { knowledge }\end{array}$ & $\begin{array}{l}\text { Teaching, through } \\
\text { reciprocal com- } \\
\text { munity engage- } \\
\text { ment, with em- } \\
\text { phasis on learning } \\
\text { outcomes related } \\
\text { to civic engage- } \\
\text { ment }\end{array}$ & $\begin{array}{l}\text { Teaching, ground- } \\
\text { ed in their person- } \\
\text { al commitment } \\
\text { to a particular } \\
\text { community }\end{array}$ \\
\hline $\begin{array}{l}\text { Boyer's Forms of } \\
\text { Scholarship }\end{array}$ & $\begin{array}{l}\text { An Intersected } \\
\text { Perspective on } \\
\text { Scholarship }\end{array}$ & $\begin{array}{l}\text { Scholarship of } \\
\text { Application }\end{array}$ & $\begin{array}{l}\text { Scholarship of } \\
\text { Engaged Re- } \\
\text { search }\end{array}$ & $\begin{array}{l}\text { Scholarship of } \\
\text { Engaged Teach- } \\
\text { ing }\end{array}$ & $\begin{array}{l}\text { Scholarship of } \\
\text { Engaged Teach- } \\
\text { ing }\end{array}$ \\
\hline $\begin{array}{l}\text { Morton's } \\
\text { Paradigm }\end{array}$ & Project-Based & Direct Service & Social Change & Value all Three & Social Change \\
\hline $\begin{array}{l}\text { Primary } \\
\text { Community }\end{array}$ & The Academy & $\begin{array}{l}\text { Individuals or } \\
\text { Specific Organi- } \\
\text { zations }\end{array}$ & $\begin{array}{l}\text { Specific Popula- } \\
\text { tion or Communi- } \\
\text { ty (external to the } \\
\text { college) }\end{array}$ & $\begin{array}{l}\text { Global (local and } \\
\text { international) }\end{array}$ & $\begin{array}{l}\text { Their Own Com- } \\
\text { munity (external } \\
\text { to the college) }\end{array}$ \\
\hline Distinct Attribute & $\begin{array}{l}\text { See the four } \\
\text { forms of scholar- } \\
\text { ship as being mu- } \\
\text { tually reinforcing, } \\
\text { resulting in better } \\
\text { informed practice } \\
\text { in their field, } \\
\text { which ultimately } \\
\text { benefits the larger } \\
\text { community. }\end{array}$ & $\begin{array}{l}\text { Collaborate } \\
\text { across disciplines } \\
\text { to address com- } \\
\text { munity needs and } \\
\text { engage students } \\
\text { in real world con- } \\
\text { texts where they } \\
\text { apply disciplinary } \\
\text { knowledge. }\end{array}$ & $\begin{array}{l}\text { Hold an as- } \\
\text { set-based view of } \\
\text { the community, } \\
\text { respect communi- } \\
\text { ty voice and value } \\
\text { on reciprocal } \\
\text { campus-commu- } \\
\text { nity partnerships. }\end{array}$ & $\begin{array}{l}\text { Have a balanced } \\
\text { committed to both } \\
\text { student learning } \\
\text { and community } \\
\text { benefit. }\end{array}$ & $\begin{array}{l}\text { Identify as com- } \\
\text { munity members } \\
\text { first, scholars } \\
\text { second. }\end{array}$ \\
\hline
\end{tabular}

academic theory and the researcher's curiosity, disconnected from community context). However, when this narrow conceptualization of "research" was expanded to Boyer's broader notion of discovery that includes the community context, focus group participants (in particular the RCC faculty) discussed the extent to which they felt their community-engaged approach ensures that their research is relevant, meaningful, and informed. This process and relationship with the community is at the heart of why they create new knowledge. They embrace their professional responsibility to actively research the complex, evolving issues facing communities. Yet, not all types prefer this approach. Participants differed in the role they believed the community should play in defining the research problem, collecting data, and interpreting findings.

While all of the types agreed on the importance of discovery and expressed support for Boyer's SOE, they differed in the extent to which they felt comfortable with and utilized all four forms of scholarship. They also varied on the extent to which they believed all four types of scholarship were valued by colleagues and their institution. In reflecting on the findings and focus groups, new questions emerged about the extent to which the appreciation for all four types of scholarship among communityengaged faculty would be shared by faculty who do not practice CES. Each of these issues warrant further exploration and examination. 


\section{Orientations to Service}

All five factors appreciated Morton's (1995) three paradigms of service, understanding the need to address both immediate needs and root causes. However, each type preferred a particular paradigm, differing on where and how they saw themselves and their role as faculty in most effectively addressing those concerns. For example, CAK faculty preferred to address immediate needs, while CA faculty preferred to advocate for social change.

Before discussing further, it is important to consider that during the final meaning-making focus groups, participants had a strong negative reaction to the term charity. The participants defined charity in different ways that included everything from religious connotations, limited effectiveness, temporary solutions, deficit or needs-based perceptions, and problematic power differentials. This finding echoes Morton's (1995) assertion that the term charity has devolved to "individuals trying to do good things ... los[ing] much of its power to transform individual or community" (p. 26). While participants did not like the term, they resonated with Morton's meaning behind the term and preferred using the phrase "direct service" to refer to the charity paradigm. Thus, to increase understanding and avoid the negative (and limited) connotations of charity, we refer to Morton's charity paradigm as direct service. However, this finding raises a deeper question about whether the language of CES and its perceived meanings draws or repels faculty from participating.

Similar to meaning embedded in language and given their own orientation, faculty may have implicit assumptions about students' orientations to service. These conceptualizations may affect how faculty design, implement, and evaluate CES when working with students as well as reveal their deeper beliefs about how community transformation and student learning occurs. For instance, research shows that college student service-learners prefer a paradigm of charity to social change (Bringle, Hatcher, \& McIntosh, 2006) and that matching students' service orientation preference with the type of service experience resulted in greater satisfaction with students' studies, increased feelings of interpersonal effectiveness and leadership, and greater learning about the community (Moely, Furco, \& Reed, 2008). Thus, questions emerge about how similarities and differences in service orientations between students and faculty may hinder or inspire deeper learning by shifting from thin to thick service experiences. Given the critical role faculty play in creating optimal learning experiences, more understanding of their service paradigms and the interaction with that of students is needed.
The CEF Typology can support the continued research on the alignment of faculty and student service paradigms by offering insight into the identification of faculty orientations to service. Our focus group findings challenged the assumption that faculty members' paradigms of service can be accurately discerned by observing how they engage students in the community. For instance, since TACV faculty value all three paradigms of service and see their primary scholarly contribution as teaching students to be informed and involved citizens, they find ways to reflect on all types of service to address larger issues surrounding civic engagement. CA faculty value social change and see their primary scholarly contribution as connecting knowledge to communities where it can make a real difference. While CA faculty may engage students in direct or project-based service, their aim is to use that experience to add context to student reflections on systemic inequity and social justice. Clearly, the type of student community engagement chosen by a faculty member should not automatically be used as a proxy for understanding faculty approaches. It is therefore necessary to build greater understanding of faculty orientations to service, rather than assuming their orientation based on their practice.

\section{Conceptualizing the Intersections of Scholarship and Service}

Our work supports Boyer's (1990, 1996) assertion that a broader, more inclusive understanding of what it means to be a scholar is needed in academia today. As he posits,

knowledge is acquired through research,
through synthesis, through practice, and
through teaching. We acknowledge that these
four categories - the scholarship of discovery,
of integration, of application, and of teaching
- divide intellectual functions that are tied in-
separably to each other. Still, there is value,
we believe, in analyzing the various kinds of
academic work, while also acknowledging that
they dynamically interact, forming an interde-
pendent whole. (1990, pp. 24-25)

As with Boyer, our study found that these aspects of knowledge creation are inseparable and interdependent. Each approach to CES, like fabric, "emerge[s] only as the forms of intellectual activity inform and enrich each other, even as patterns and textures of tapestries depend on how various threads are woven together" (Colbeck \& Wharton-Michael, 2006, pp. 18-19). With this understanding in place, it is then possible to explore the various threads that comprise each approach without dissecting it, un- 
raveling the fabric, and destroying its essence. In examining the composition of each type, we learn that Boyer's forms of scholarship intersect in distinct ways and for different purposes, depending on the underlying service paradigm, which results in a unique overall perspective on the purpose of CES. While faculty from all types understand the value of all four of Boyer's forms of scholarship and all three of Morton's paradigms of service, for most faculty, one form of scholarship and one paradigm of service emerge as the most salient or meaningful to their work.

\section{Faculty Identity and Contributions}

Faculty identity surfaced as a key distinction among community-engaged faculty. Where do they anchor their identities: in the community or in the academy? For example, CA faculty identify as community members whose paid work happens to be in higher education, while EAF faculty identify strongly as academics whose work is made more meaningful when they can apply it to community contexts. Similarly, participants also varied by type with regard to where they feel they make their greatest scholarly contribution. For example, RCC and EAF faculty believe their greatest contribution is through research that informs community action, whereas TACV faculty believe their greatest contribution is through teaching students to be (more) informed, active citizens.

\section{Limitations and Implications}

The CEF Typology offers empirical insights into the variety of approaches faculty take toward CES, which can be used to deepen understanding and customize resources, training, and policies for supporting CES among individual and groups of faculty. At the same time, the typology has limitations, which need to be taken into account when considering the implications for additional research, theory, and practice.

\section{Research}

These findings should be considered in light of the study's context at a comprehensive private notfor-profit university. Future study should examine whether or not the current CEF Typology needs to be modified to encompass faculty perspectives from other locations and institutional types, including community colleges, small liberal arts institutions, religiously affiliated institutions, HBCU's, Hispanic Serving Universities, Tribal Colleges, and public (particularly land-grant) institutions.
In addition to the sole site limitation, the findings are also limited by the Q Set items. For instance, when analyzing the Q Sorts and facilitating the subsequent focus groups, the meaning and definition of community emerged as a distinguishing issue among some of the faculty types. Some faculty conceptualized the community as specific partners with whom they work in their local community; other faculty held a broad conceptualization of "community," referring to the general public or the civic sphere. Similarly, we interpreted the extent to which CEF consider themselves to be internal or external to the community based on their Q Sorts. Future examinations of this typology should include items in the Q Set that more explicitly allow participants to express more fully how they conceptualize "community" and how they see themselves related to that community (i.e., internal or external to that community).

Finally, further quantitative research, in particular, is needed to explore questions related to prediction in the general population. For example, what proportion of $\mathrm{CEF}$ does each type represent (i.e., are some types more rare than others?); to what extent do certain academic disciplines or contract types correlate with the CEF type?; are some types more or less likely to thrive at certain types of institutions?; does type correlate with student learning outcomes?; and, how does each type correlate with positive community impact? Additionally, recognizing the implications of an increasingly diverse faculty (Kezar \& Maxey, 2015; Saltmarsh \& Hartley, 2016), future research should examine whether aspects of personal background such as gender, age, and ethnicity statistically correlate with a particular type. Future studies should also consider asking participants about any religious or political affiliations, as these emerged in the focus groups as salient identities for a few participants.

\section{Theory}

One of the strengths of this Q study is that faculty were able to offer their perspective on CES without being constrained by operationalized variables defined by us as the researchers. Nevertheless, the Q Set and, in turn, the participant responses were limited to the broader options provided by our theoretical framework (Boyer 1990, 1996; Morton,1995). Given that a typology of faculty approaches to CES emerged in this study, future research should incorporate additional perspectives articulated in the literature (e.g., Barker, 2004; Demb \& Wade, 2012; Fear \& Sandmann, 1995; Perry \& Wise, 1990; Saltmarsh \& Hartley, 2016; Westheimer \& Kahne, 2004) in order to make further distinctions within 
and between the types, as well as contribute to theories regarding community-engaged faculty.

Recognizing these limitations, the CEF Typology offers a new lens through which to view the extant literature on community-engaged faculty in both challenging and complementary ways. First, the existing literature can be (re)viewed with a critical eye using the CEF Typology to reveal gaps in the representation of faculty experiences. For instance, when looking at Barker's (2004) practice of "community partnership," there appears to be alignment with CA and TACV faculty. However, EAF faculty may not see their approach to practice represented. Second, the existing literature can be viewed alongside the CEF Typology in an effort to identify areas of complementarity. For example, when examining O'Meara's (2008) work on faculty motivations for CES with this study's CEF Typology, it may be that certain kinds of motivation encourage some faculty types more than others [e.g., "achieve disciplinary goals" (O’Meara, p. 14) may motivate EAF or CAK faculty most]. Janke and Colbeck (2008) found that several aspects of CES (e.g., increased meaningfulness of their work and feedback resulting from knowing the actual results of their scholarship for community members) resulted in a "high internal motivation" for their engaged work (p. 38), which may best align with the CA, RCC, and TACV types. Thus, reconsidering the literature in light of the CEF Typology may generate or refine existing theory, as well as inspire future research.

One of the key contributions of this study to future theory development is the finding that confirms community-engaged faculty are not a homogenous group. To date, much of our existing theory on faculty approaches to CES classifies faculty by externally observed variables such as discipline (Buzinski et al., 2013; Townson, 2009) or practice (Barker, 2004; Pearl, 2015) in an effort to make the complexity more manageable. However, the results of our study suggest that these researcher-defined categories may not necessarily represent a distinct, shared way of conceptualizing CES. Consequently, generalizations based on these studies may be limited due to false assumptions that faculty within the researcher-defined groups held similar perspectives on their CES. Thus, it may be insightful to reexamine studies that may have inadvertently viewed faculty as a homogenous group to determine if their findings still hold in light of the CEF Typology.

Related to the issue of homogeneity, communityengaged faculty may experience feeling marginalized. Faculty marginalization is not limited to differences between community-engaged scholars and those who are not (O'Meara, 2002a). Rather, our study confirmed that faculty marginalization can occur within the community of engaged faculty itself. Prior to presenting the types to the focus groups, most of the faculty viewed their approach as "the right way" and the other types' approaches as representing a less effective approach. Moreover, when we presented the types, it was clear that for many faculty there were certain types with which they did not want to be associated. However, in discussing each of the types more fully and clarifying the description of each type, the participants began to express greater appreciation for others' efforts and accomplishments. By becoming aware of shared perspectives and differences, faculty were able to critically reflect on their own perspective, as well as that of others, offering potential insights into how to support greater diversity within the academic ranks (Kezar \& Maxey, 2015; Post et al., 2016; Welch, 2016).

\section{Practice}

The use of typologies in practice should be done with great care. Typologies can facilitate understanding another person's point of view and appreciating the benefits of diverse perspectives and approaches. Using typologies in this way can deepen relationships based on that understanding and appreciation. However, there is the potential to misuse typologies as a substitute for relationship-building, making decisions on type-based assumptions rather than actually getting to know one another. With this understanding, there are specific implications for supporting faculty development and for partnering with communities.

Faculty support and development. The CEF Typology has implications for how faculty and administrators approach faculty development and support community-engaged faculty if they want to increase the amount and quality of engaged scholarship (Glassick, Huber, \& Maeroff, 1997) on their campuses. First, they need to understand from where faculty are coming in order to customize faculty training and support (Welch, 2016; Welch \& Plaxton Moore, 2016). As O'Meara and Rice (2005) remind us, the aims of the SOE require faculty to "move beyond "outreach" and that scholars "go beyond "service." The CEF typology revealed that several types (RCC, CA, and many faculty in TACV) already share the values described by O'Meara and Rice, while others (EAF, CAK, and some TACV) represent "service" and "outreach" models. Second, each type may need different support. For instance, it is unlikely that CA faculty would need assistance finding community partners with whom to work since they have strong ties to their community. However, CAK faculty may seek 
assistance with identifying partners from servicelearning administrators. Finally, by knowing faculty members' respective approaches to CES, administrators can identify particular resources that may help faculty either strengthen or complement their approach so as to reflect and intentionally design syllabi, course learning objectives, assignments, and assessments.

By intentionally working as a catalyst that connects faculty to each other across types, centers that serve faculty may be able to maximize the unique strengths of each factor, resulting in service project collaborations or co-authorships that benefit faculty, communities, students, and the institution. Specifically, centers can make best use of limited personnel and funding by encouraging faculty-tofaculty mentorship. The CEF Typology suggests not only areas for faculty development unique to each type, but also indicates how and which faculty type might be best suited to provide that assistance. For example, CAK faculty may benefit from workshops or mentoring on facilitating reflections that help students connect their applied experience to broader concepts of civic capacity and civic responsibility. CA and TACV faculty may be particularly helpful in providing that mentoring. CA, CAK, and TACV faculty may be more interested in sharing their work with community members than publishing their work in peer-reviewed journals. RCC and EAF faculty might have a convincing voice on why it is important to share their work with the field more broadly, as well as may be able to offer tips on how to publish CES in more traditional outlets.

This study also supports previous research that calls for an end to "one size fits all" approaches to faculty support, development, and recognition efforts for community-engaged scholars (Buzinski et al., 2013; Pearl, 2015). Engaged faculty are not a homogenous group. Instead, the typology suggests different kinds of campus advocacy that could support each type. For example, to the extent that institutions have been intentional about attracting and supporting community-engaged faculty, those efforts have largely focused on making promotion and tenure processes more transparent in terms of how engaged scholarship will be evaluated for impact and rigor (O'Meara \& Rice, 2005). The results of this study suggest that the traditional processes of promotion and tenure are likely to support EAF faculty the most, followed by RCC. Revising promotion and tenure processes to include community-engaged work should help all of the types, not just EAF and RCC, and the CEF Typology offers promotion and tenure committee members with a framework from which to understand and recognize different approaches to
CES. More substantive reforms are needed to fully recognize and integrate research, teaching, and service, which previously have been viewed as distinct work (Kezar \& Maxey, 2015; O’Meara, 2002b). The typology also serves as a reminder that CEF, just as the majority of faculty in higher education (Williams June, 2012), generally are no longer a part of the tenure-track trajectory. Further research examining the reward systems that attract and retain high quality CEF who have fixed-term, parttime, clinical, or adjunct appointments are needed and would address the call for higher education to recognize the shift in faculty contract types (Kezar \& Maxey).

The typology can be useful for building a sense of community among engaged faculty by helping them appreciate and work with faculty who have a different perspective. Faculty often unconsciously evaluate each other's work through the lens of their own type, making it natural for some to see a different approach in a negative light. "She just doesn't get it" or "he doesn't really do service-learning" are common laments. The typology can help faculty not only see each other's work from the perspective of other types (i.e., coming to recognize, appreciate, and hopefully understand the different priorities and aims), but also engage in genuine collaboration, which has been identified as being essential to advancing engaged scholarship (O'Meara \& Rice, 2005). Working with complementarity, faculty and institutions can generate a supportive community in which engaged faculty do their work, integrate unique disciplinary perspectives in ways that grapple with complex problems, and improve the way our collective efforts impact our communities. The CEF Typology paves the way for a broader appreciation for the way others approach CES and can be leveraged to promote this kind of genuine collaboration and community

Community Partnerships. While beyond the scope of this research study, the CEF Typology may also be useful for community partners. The typology may inform the creation of tools to help community partners understand how a particular faculty member is approaching a partnership and can help community members establish mutuallybeneficial collaborative partnerships. With a better understanding of the different ways that faculty conceptualize the meaning of community-engaged work, community partners may be better able to recognize which faculty have the intrinsic goals most likely to result in a truly mutually beneficial partnership (e.g., applying disciplinary expertise, teaching civic values, or grounding research in community context). Insight into the perspectives each faculty type has on CES may also better prepare 
community partners to communicate with faculty about the nature of the campus-community partnership they hope to foster. Future research should examine what community partners' experiences are like when working with each type of faculty, as well as the extent to which greater understanding of the types affects the quality of and satisfaction with the partnership for all involved.

\section{Conclusion}

This research refines our understanding of community-engaged faculty, presenting identifiable ways that faculty differ in how they define and approach CES. In exploring the variety of ways in which faculty make meaning of CES using a range of perspectives on scholarship (Boyer, 1990) and service (Morton), the CEF Typology emerged with five different approaches. One type is not better than another per se. Rather, by having a more precise understanding of community-engaged faculty, efforts to support CES may be more concrete, specific, and effective. It is one thing to suggest that approaches differ and quite another to name and describe those differences in the form of paradigms that allow scholars to understand, appreciate, and even collaborate with alternative perspectives. This typology may open the door to conversations, theory, and research that further illuminate the ways that community-engaged faculty differ in the aims and meaning of their work. By further exploring and deepening the collective understanding of the unique approaches to CES (with its inherent strengths and limitations), faculty may have a stronger framework and additional language with which to articulate their unique scholarly contributions (Boyer, 1990); communities may benefit from more intentionally integrated work; and colleges and universities may be better equipped to support, develop, recognize, and reward the contributions of all of its faculty while fulfilling its civic purpose.

\section{References}

Abes, E. S., Jackson, G., \& Jones, S. R. (2002). Factors that motivate and deter faculty use of service-learning. Michigan Journal of Community Service Learning, 9(1), 5-17

Armenta, B. E. (2010). Stereotype boost and stereotype threat effects: the moderating role of ethnic identification. Cultural Diversity and Ethnic Minority Psychology, 16(1), 94-98.

Astin, A. W., \& Sax, L. J. (1998). How undergraduates are affected by service participation. Journal of College Student Development, 39(3), 251-263.
Astin, A. W., Sax, L. J., \& Avalos, J. (1999). Long-term effects of volunteerism during the undergraduate years. The Review of Higher Education, 22, 187-202.

Astin, A. W., Vogelgesang, L. J., Ikeda, E.K, \& Yee, J. A. (2000). Executive summary: How service learning affects students. Los Angeles: Higher Education Research Institute, UCLA.

Austin, A. E. \& Gamson, Z. F. (1983). Academic workplace: New demands, heightened tensions. Washington, D.C.: Association for the Study of Higher Education.

Bailey, K. D. (1994). Typologies and taxonomies: An introduction to classification techniques (Sage University Paper series on Quantitative Applications in the Social Sciences, series no. 07-102). Thousand Oaks, CA: Sage.

Barker, D. (2004). The scholarship of engagement: A taxonomy of five emerging practices. Journal of Higher Education Outreach and Engagement, 9(2), 123-137.

Boyer, E. L. (1990). Scholarship reconsidered: Priorities of the professoriate. Stanford, CA: The Carnegie Foundation for the Advancement of Teaching.

Boyer, E. L. (1996). The scholarship of engagement. Bulletin of the American Academy of Arts Orchestrating Change at a Metropolitan University. Metropolitan Universities, 18(3), 57-74.

Bringle, R. G., Hatcher, J. A., \& McIntosh, R. E. (2006). Analyzing Morton's typology of service paradigms and integrity. Michigan Journal of Community Service Learning, 13(1), 5-15.

Brown, S. R. (1980). Political subjectivity: Applications of $Q$ Methodology in political science. New Haven, CT: Yale University Press.

Burawoy, M. (2005). For public sociology. American Sociological Review, 70(1), 4-28.

Buzinski, S.G., Dean, P., Donofrio, T.A., Fox, A., Berger, A.T., Heighton, L.P., Selvi, A.F., \& Stocker, L.H. (2013). Faculty and administrative partnerships: Disciplinary differences in perceptions of civic engagement and service-learning at a large, research-extensive university. Partnerships: A Journal of Service-Learning \& Civic Engagement, 4(1), 45-75.

The Carnegie Classification of Institutions of Higher Education (n.d.). About Carnegie Classification. Retrieved (October 28, 2016) from http://carnegieclassifications.iu.edu/.

Colbeck, C. L., \& Wharton-Michael, P. (2006). Individual and organizational influences on faculty members' engagement in public scholarship. New Directions for Teaching and Learning, 105, 17-26.

Delve, C. I., Mintz, S. D., \& Stewart, G. M. (1990). Promoting values development through community service: A design. In C. I. Delve, S. D. Mintz, \& G. M. Stewart (Eds.), Community service as values education. New Directions for Student Services \#50 (pp. 7-29). San Francisco: Jossey-Bass.

Demb, A., \& Wade, A. (2012). Reality check: Faculty involvement in outreach \& engagement. The Journal of Higher Education, 83(3), 337-366. 
Ehrlich, T. (Ed.) (2000). Civic responsibility and higher education. Phoenix, AZ: Oryx Press.

Eyler, J., Giles, D., Jr., \& Braxton, J. (1997). The impact of service-learning on college students. Michigan Journal of Community Service Learning, 4(1), 5-15.

Eyler, J., \& Giles, D., Jr. (1999). Where's the learning in service-learning? San Francisco: Jossey-Bass.

Fear, F., \& Sandmann, L. R. (1995). Unpacking the service category: Reconceptualizing university outreach for the $21^{\text {st }}$ century. Continuing Higher Education Review, 59(3), 110-122.

Fear, F. A., \& Sandmann, L. (2016). The "new" scholarship: Implications for engagement and extension. Journal of Higher Education Outreach and Engagement, 20(1), 101-112.

Fitzgerald, H. E., Bruns, K., Sonka, S., Furco, A., \& Swanson, L. (2016). The centrality of engagement in higher education. Journal of Higher Education Outreach and Engagement, 20(1), 223-243.

Furco, A. (1996). Service learning: A balanced approach to experiential education. In J. Raybuck (Ed.), Expanding boundaries: Serving and learning (pp. 2-6). Washington, DC: Corporation for National Service.

Furco, A. (2001). Advancing service-learning at research universities. In M. Canada \& B. W. Speck (Eds.), Developing and Implementing Service-Learning Programs. New Directions for Higher Education \#114 (pp. 67-78). San Francisco: Jossey-Bass.

Furco, A. (2010). The engaged campus: Toward a comprehensive approach to public engagement. British Journal of Educational Studies, 58(4), 375-390.

Glass, C., Doberneck, D., \& Schweitzer, J. (2011). Unpacking faculty engagement: The types of activities faculty members report as publicly engaged scholarship during promotion and tenure. Journal of Higher Education Outreach and Engagement, 15(1), 7-30.

Glassick, C. E., Huber, M. T., \& Maeroff, G. I. (1997). Scholarship assessed: Evaluation of the professoriate. San Francisco: Jossey-Bass.

Janke, E. M., \& Colbeck, C. L. (2008). An exploration of the influence of public scholarship on faculty work. Journal of Higher Education Outreach and Engagement, 12(1), 31-46.

Kezar, A. J, Chambers, A. C., \& Burkhardt, J. C. (Eds.). (2005). Higher education for the public good: Emerging voices from a national movement. San Francisco: Jossey-Bass.

Kezar, A., \& Maxey, D. (2015). Adapting by design. Delphi Project on the changing faculty and student success. Retrieved from http://www.uscrossier. org/pullias/wp-content/uploads/2015/06/DELPHIPROJECT_ADAPTING-BY-DESIGN_2ED.pdf

Jacoby, B. (2015). Service-learning essentials. San Francisco: Jossey-Bass.

Kendall, J. C. (1990). Combining service and learning: An introduction. In J. C. Kendall \& Associates (Eds.), Combining service and learning: A resource book for community and public service, Vol. 1 (pp. 1-36). Raleigh, NC: National Society for Internships and Experiential Education.
Kretzmann, J.P., \& McKnight, J. L. (1993). Building communities from the inside out: A path towards finding and mobilizing a community's assets. Evanston, IL: Center for Urban Affairs and Policy Research, Northwestern University.

Lynton, E. A. (1994) Knowledge and scholarship. Metropolitan Universities: An International Forum, 5(1), 9-17.

Lynton, E. A. (1995). Making the case for professional service. Washington, DC: American Association for Higher Education.

McKeown, B., \& Thomas, D. (1988). Q Methodology. Newbury Park, CA: Sage.

Moely, B. E., Furco, A., \& Reed, J. (2008). Charity and social change: The impact of individual preferences on service-learning outcomes. Michigan Journal of Community Service Learning, 15(1), 37-48.

Morf, M. E., Miller, C. M., \& Syrotuik, J. M. (1976). A comparison of cluster analysis and Q factor analysis. Journal of Clinical Psychology, 32(1), 59-64.

Morrison, E. A., \& Wagner, W. (2016). Exploring faculty perspectives on community-engaged scholarship: The case for Q Methodology. Michigan Journal of Community Service Learning, 23(1), 5-14.

Morton, K. (1995). The irony of service: Charity, project and social change in service-learning. Michigan Journal of Community Service Learning, 2(1), 19-32.

Newman, F. (1985). Higher education and the American resurgence. Princeton, NJ: Carnegie Foundation for the Advancement of Teaching.

O'Meara, K. (2002a). Scholarship unbound: Assessing service as scholarship for promotion and tenure. London, England: Routledge.

O'Meara, K. (2002b). Uncovering the values in faculty evaluation of service as scholarship. The Review of Higher Education, 26(1), 57-80.

O'Meara, K. (2008). Motivation for faculty community engagement: Learning from exemplars. Journal of Higher Education Outreach and Involvement, 12(1), 7-29.

O’Meara, K. (2016). Legitimacy, agency, and inequality: Organizational practices for full participation of community-engaged faculty. In M. A. Post, E. Ward, N. V. Longo, \& J. Saltmarsh (Eds.), Publicly engaged scholars: Next-generation engagement and the future of higher education (pp. 96-109). Sterling, VA: Stylus.

O’Meara, K., \& Niehaus, E. (2009). Service-learning is . . . How faculty explain their practice. Michigan Journal of Community Service Learning, 16(1), 17-32.

O’Meara, K., \& Rice, R. E. (2005). Faculty priorities reconsidered: Rewarding multiple forms of scholarship. San Francisco: Jossey-Bass.

O’Meara, K., Sandmann, L.R., Saltmarsh, J., \& Giles, D.E. (2010). Studying the professional lives and work of faculty involved in community engagement. Innovative Higher Education, 36, 83-96.

Pearl, A. J. (2015). Community-engaged scholarship in the professoriate: A mixed-methods exploration 
of faculty motivations, satisfaction, and productivity. (Unpublished doctoral dissertation). University of Georgia, Athens, GA.

Post, M. A., Ward, E., Longo, N. V., \& Saltmarsh, J. A. (Eds.). (2016). Publicly engaged scholars: Next generation engagement and the future of higher education. Sterling, VA: Stylus Publishing.

Porter-Honnet \& Poulsen, (1990). Principles of good practice in combining service and learning. In J. C. Kendall \& Associates (Eds.), Combining service and learning: A resource book for community and public service, Vol. 1. Raleigh, NC: National Society for Internships and Experiential Education.

Rice, R. E. (1996). Making a place for the new American scholar (New Pathways Inquiry No. 1). Washington, DC: American Association for Higher Education.

Rice, R. E., Sorcinelli, M. D., \& Austin, A. E. (2000). Heeding new voices: Academic careers for a new generation. Washington, DC: American Association for Higher Education.

Saltmarsh, J. (2011a). The civic promise of servicelearning. In J. Saltmarsh \& E. Zlotkowski (Eds.), Higher education and democracy: Essays on servicelearning and civic engagement (pp. 28-34). Philadelphia: Temple University Press.

Saltmarsh, J. (2011b). Engagement and epistemology. In J. Saltmarsh \& E. Zlotkowski (Eds.), Higher education and democracy: Essays on service-learning and civic engagement (pp. 342-353). Philadelphia: Temple University Press.

Saltmarsh, J., \& Hartley, M. (2016). The inheritance of next-generation engagement scholars. In M. A. Post, E. Ward, N. V. Longo, \& J. Saltmarsh (Eds.), Publicly engaged scholars: Next-generation engagement and the future of higher education (pp. 15-33). Sterling, VA: Stylus.

Sandmann, L. R. (2008). Conceptualization of the scholarship of engagement in higher education: A strategic review, 1996-2006. Journal of Higher Education Outreach and Engagement, 12(1), 91-104.

Schmolck, P. (2002). PQMethod manual. Retrieved from http://www.rz.unibw- muenchen.de/ p41bsmk/ qmethod/pqmanual.htm

Schön, D. A. (1983). The reflective practitioner: How professionals think in action (Vol. 5126). Basic books.

Schön, D. A. (1987). Educating the reflective practitioner: Toward a new design for teaching and learning in the professions. San Francisco: JosseyBass.

Schön, D. A. (1995). Knowing-in-action: The new scholarship requires a new epistemology. Change: The Magazine of Higher Learning, 27(6), 27-34.

Shih, M., Ambady, N., Richeson, J. A., Fujita, K., \& Gray, H. M. (2002). Stereotype performance boosts: The impact of self-relevance and the manner of stereotype activation. Journal of Personality and Social Psychology, 83(3), 638-647.

Sigmon, R. (1994). Serving to learn, learning to serve. In Linking Service with Learning. Washington, DC: Council for Independent Colleges.
Stanton, T. K. (2008). New times demand new scholarship: Opportunities and challenges for civic engagement at research universities. Education, Citizenship, and Social Justice, 3(1), 19-42.

Stanton, T. K., Giles, Jr., D. E. \& Cruz, N. I. (1999). Service-Learning: A movement's pioneers reflect on its practice and future. San Francisco: Jossey-Bass.

Steele, C. M., \& Aronson, J. (1995). Stereotype threat and the intellectual test performance of African Americans. Journal of Personality and Social Psychology, 69(5), 797-811.

Stephenson, W. (1953). The study of behavior: $Q$ Technique and its methodology. Chicago: The University of Chicago Press.

Townson, L. (2009). Engaged scholarship at land-grant institutions: Factors affecting faculty participation. (Doctoral dissertation). Retrieved from Dissertations and Theses database. (UMI No. 3363733)

Wade, A., \& Demb, A. (2009). A conceptual model to explore faculty community engagement. Michigan Journal of Community Service Learning, 15(2), 5-16.

Ward, K. (2003). Faculty service roles and the scholarship of engagement. San Francisco: Jossey-Bass.

Watts, S., \& Stenner, P. (2005). Doing Q Methodology: Theory, method and interpretation. Qualitative Research in Psychology, 2(1), 67-91.

Welch, M. (2016). Engaging higher education: Purpose, platforms, and programs for community engagement. Sterling, VA: Stylus.

Welch, M. \& Plaxton Moore, S. (2016, September). Faculty development for service-learning and community engagement in higher education: A review of the literature and survey of current trends. Presentation at the annual conference of the International Association for Research in Service-Learning and Community Engagement, New Orleans, LA.

Westheimer, J., \& Kahne, J. (2004). What kind of citizen? The politics of educating for democracy. American Educational Research Journal, 41(2), 237-269.

Williams June, A. (2012, November 5). Adjuncts build strength in numbers. The Chronicle of Higher Education. Retrieved from: http://chronicle.com/article/ Adjuncts-Build-Strength-in/135520/

Zlotkowski, E. (2011). Social crises and the faculty response. In J. Saltmarsh \& E. Zlotkowski (Eds.), Higher education and democracy: Essays on service-learning and civic engagement (pp. 13-27). Philadelphia: Temple University Press.

\section{Authors}

EMILY MORRISON (Emily_m@gwu.edu) is the director of the Human Services and Social Justice Program and an assistant professor of Sociology at The George Washington University in Washington, DC. Before becoming faculty, she directed volunteer and service-learning programs at both the undergraduate and graduate levels, as well as founded a 501(c)3 nonprofit organization. Mor- 
rison received a B.S. in Psychology from Kansas State University, an M.A. in College Student Personnel from the University of Maryland, and her Ed.D. in Human and Organizational Learning from The George Washington University.

WENDY WAGNER (wagnerw@gwu.edu) is the senior coordinator for Academic Service-Learning at the Honey W. Nashman Center for Civic Engagement and Public Service, as well as an adjunct professor in Human Services and Social Justice at The
George Washington University in Washington, DC. Prior to her current roles, she was the director of the Center for Leadership and Community Engagement at George Mason University. Wagner received a B.A. in Communication Studies from the University of Nebraska-Lincoln, an M.A. in College Student Personnel from Bowling Green State University, and her Ph.D. in College Student Development from the University of Maryland-College Park. 